\title{
Pure autonomic failure
}

INSERM

\section{Source}

INSERM. (1999). Orphanet: an online rare disease and orphan drug data base. Pure autonomic failure. ORPHA:441

Pure autonomic failure (PAF) is a neurodegenerative disease that affects the sympathetic branch of the autonomous nervous system and that manifests with orthostatic hypotension. 